\title{
Acute limb ischemia due to paradoxical embolism treated with systemic thrombolysis
}

\author{
Veronika Pokorna', Svetlana Bodikova', Jozef Kaluzay', Zuzana Liskova², Olga Jurkovicova' \\ $14^{\text {th }}$ Department of Internal Medicine, Faculty of Medicine, Comenius University in Bratislava and University \\ Hospital Bratislava, St. Cyril and Method Hospital, Slovak republic \\ ${ }^{2}$ Rádiológia, s. r. o., University Hospital Bratislava, St. Cyril and Method Hospital, Slovak Republic
}

\begin{abstract}
We present a case report of a patient with acute upper and lower limb ischemia due to paradoxical embolism. A 67-year old woman without history of venous thromboembolism suffered dislocated patellar fracture requiring surgery in November 2017. Two months after surgery she presented to the emergency room with bilateral pulmonary embolism, occlusion of the left subclavian artery, left common femoral artery and superior mesenteric artery. Transesophageal echocardiography detected patent foramen ovale. Vascular surgeon decided against embolectomy, interventional radiologist against pharmacomechanical thrombolysis due to the extent of the occlusions. Systemic thrombolysis (alteplase) was administered successfully with resolution of the emboli in the left subclavian artery, left common femoral artery and superior mesenteric artery.
\end{abstract}

Key words: acute limb ischemia, orthopedic surgery, paradoxical embolism, patent foramen ovale, systemic thrombolysis, venous thromboembolism.

\section{Akútna končatinová ischémia v dôsledku paradoxnej embolizácie liečená systémovou trombolýzou}

Predstavujeme prípad pacientky s akútnou ischémiou na hornej aj dolnej končatine v dôsledku paradoxnej embolizácie. 67-ročná žena bez anamnézy venózneho tromboembolizmu utrpela v novembri 2017 dislokovanú fraktúru pately s potrebou operačného riešenia. Dva mesiace po operácii bola rehospitalizovaná pre obojstrannú embóliu do arteria pulmonalis, oklúziu lavej arteria subclavia, lavej arteria femoralis communis a arteria mesenterica superior. Transezofageálna echokardiografia zistila prítomnost' foramen ovale patens. Cievny chirurg neindikoval embolektómiu a intervenčný rádiológ neindikoval farmakomechanickú trombolýzu z dôvodu vel'kého rozsahu oklúzie. Následne bola úspešne podaná systémová trombolýza (altepláza) s rozpustením embolov v lavej arteria subclavia, v lavej arteria femoralis communis a v arteria mesenterica supeior. Kličová slova: akútna končatinová ischémia, ortopedická operácia, paradoxná embolizácia, foramen ovale patens, systémová trombolýza, venózny tromboembolizmus.

\section{Introduction}

Orthopedic surgery significantly increases the risk of venous thromboembolism (VTE). Major orthopedic surgery is associated with approximately twice the risk of VTE than major general surgery (1). Timing of postoperative VTE depends on the type of surgery (2). The minimum recommended pharmacological prophylaxis (10-14 days) is not always sufficient (3), resulting into deep vein thrombosis with/without pulmonary embolism. Significant pulmonary embolism elevates the pressure in right heart's chambers and might cause paradoxical embolism in patients with patent foramen ovale (10-35\% of the population) (4). The emboli can affect various arteries at the same time leading e.g. to stroke, limb ischemia or visceral ischemia. There is no best recommended therapeutical approach for the treatment of multiple-site ischemia caused by paradoxical emboli.

\section{Case description}

A 67-year old woman (height $163 \mathrm{~cm}$, weight $85 \mathrm{~kg}$, BMI $32 \mathrm{~kg} / \mathrm{m}^{2)}$ with history of arterial hypertension, thyreopathy and hypercholesterolemia, on treatment with perindopril (5 mg), amlodipin (5 mg), L-thyroxine $(50 \mu \mathrm{g})$ and atorvastatin $(10 \mathrm{mg})$ suffered an injury of left knee with dislocated patellar fracture requiring surgery of 1 hour and 
Fig. 1. Bilateral embolism into all lobar branches of the pulmonary artery. Arrows pointing towards the emboli

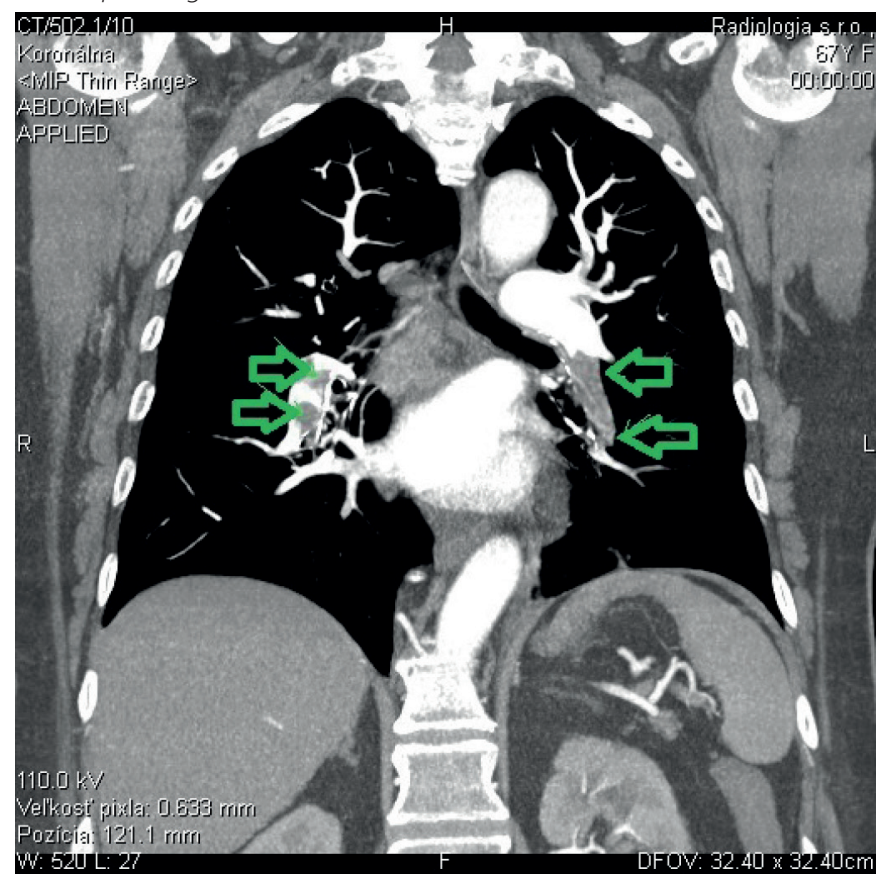

40 minutes of duration in spinal anesthesia. The intervention consisted of reposition, wiring and placement of a plaster splint (replaced 10 days later with an orthesis). She was discharged from hospital due to favorable evolution on the third day. Nadroparin $0.4 \mathrm{ml}$ subcutaneously once daily was recommended till complete mobilization. The patient was on active rehabilitation 21 days after surgery and the traumatologist decided to apply the orthesis for 7 more days and stop the low molecular weight heparin (LMWH) prophylaxis.

Two months (56-days) after surgery the patient was brought by ambulance to the Emergency Department of the University Hospital. On her way to the rehabilitation center and after getting of the car, the patient experienced sudden breathlessness, dizziness without loss of consciousness and profuse sweating. At the same time, she felt numbness in the left lower and upper extremities. On day before she had noticed swelling of the left calf. Deep vein thrombosis complicated with pulmonary embolism was suspected. D-dimer value was $>8563.60 \mathrm{mg} / \mathrm{I}$ FEU (reference range 0.00-470.00), Troponin T $56.41 \mathrm{\mu g} / \mathrm{l}$ (reference range 3-14) and NT-proBNP $342.5 \mathrm{ng} / \mathrm{l}$ (reference range 5-125). Computed tomographic (CT) pulmonary angiography confirmed the suspected diagnosis of pulmonary embolism showing bilateral embolism into all lobar branches of the pulmonary artery (fig. 1). The patient was admitted to the Intensive Care Unit in a hemodynamically stable condition (blood pressure 106/60 mm Hg, pulse rate $80 \mathrm{bpm}$ ) and treatment with nadroparin $0.8 \mathrm{ml}$ subcutaneously every 12 hours was initiated.

Subsequently the patient complained again about numbness and coldness in both the left upper and lower extremities. Pulses over left radial artery, left dorsalis pedis artery and left tibialis posterior artery were not palpable, examination with handheld Doppler system showed a mono-phasic flow over all the above-mentioned arteries. Patent fora-
Fig. 2. Occlusion (arrows) of the left subclavian artery of $7 \mathrm{~cm}$ of length at the site of the subclavian - vertebral artery bifurcation

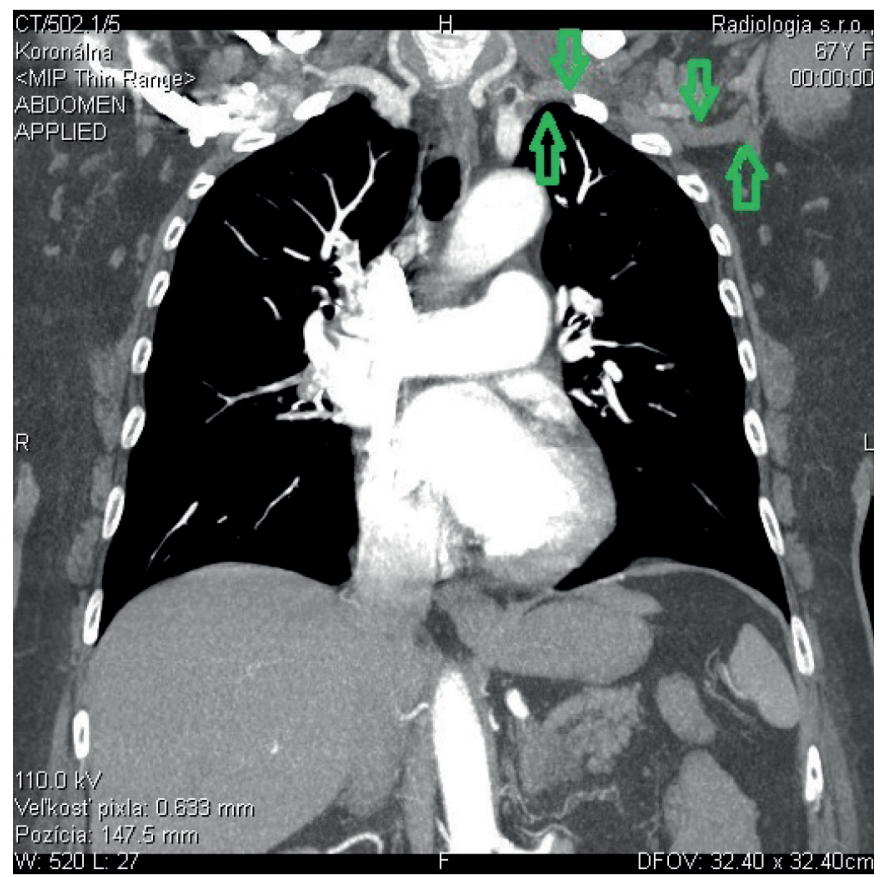

men ovale/septal defect was suspected in first place; aortic dissection was considered as well.

Transthoracic echocardiography did not detect any significant abnormality. As the transesophageal echocardiography was not readily available, CT examination of the aorta was performed. The CT scan ruled out suspected aortic dissection, however showed complete occlusion of the left subclavian artery of $7 \mathrm{~cm}$ of length at the site of the subclavian - vertebral artery bifurcation (fig. 2) and $12 \mathrm{~mm}$ long partial occlusion of superior mesenteric artery (fig. 3) without signs of intestinal ischemia.

Color Duplex ultrasound of the left upper and lower extremities confirmed the occlusion of the left subclavian artery and detected an acute obliteration of the left common femoral artery with hypoechogenic embolus extending from the transition point of the left external iliac artery into the left common femoral artery down to the bifurcation site of the left common femoral artery. No atherosclerotic changes were visible. At the same time, subacute thrombosis in the left popliteal vein was detected.

Vascular surgeon decided not to perform embolectomy at this point, with general anesthesia being of high risk due to recent pulmonary embolism and local anesthesia being not viable due to the extent of the occlusion (supratherapeutic dose of the local anesthetic would have been needed). Interventional radiologist decided against pharmacomechanical thrombolysis for the left upper and lower extremity arteries due to the extent of the finding. Therefore, vascular medicine specialist, vascular surgeon and interventional radiologist decided to administer systemic thrombolysis with alteplase (100 mg over 2 hours), followed by continuous unfractionated heparin infusion. The administration of thrombolysis occurred 22 hours after initial symptoms. 
Six hours post thrombolysis, color Duplex ultrasound showed a tri-phasic flow over the left common femoral artery down to the popliteal artery with a mono-phasic flow distally pointing towards a partial occlusion at the site of trifurcation. Thrombosis of the left popliteal vein as well as the occlusion of the left subclavian artery remained unaltered. $\mathrm{CT}$ of the abdominal aorta on the following day showed a complete recanalization of the superior mesenteric artery (fig. 4).

As the clinical finding on the left upper extremity did not require immediate surgery (no motor or sensory deficit), vascular surgeon opted for continuous intravenous heparin and reassessment 48 hours after thrombolysis. At that point complete recanalization of the subclavian artery was observed. Patient was switched back to nadroparin $0.8 \mathrm{ml}$ subcutaneously twice a day and warfarin treatment was initiated later

Contrast transesophageal echocardiography with agitated dextrose detected patent foramen ovale (PFO), the channel being $22 \mathrm{~mm}$ long and $4.2 \mathrm{~mm}$ wide following Valsalva maneuver (fig. 5). The patient is currently doing well and scheduled for the closure of the PFO.

\section{Discussion}

Venous thromboembolism (VTE) is a frequent complication of orthopedic/traumatologic surgery and develops less frequently in non-orthopedic surgery (5). According to White et al, $2.8 \%$ of patients undergoing hip arthroplasty and $2.1 \%$ of patients undergoing knee arthroplasty were diagnosed with deep vein thrombosis or pulmonary embolism within 3 months of surgery (1). The risk of VTE is highest during the first two post-operative weeks but remains elevated for 2 to 3 months $(5,6)$ and $75 \%$ of deep vein thrombosis after orthopedic surgery occur in the operated leg (7) which was also the case of our patient. Antithrombotic prophylaxis significantly reduces the risk of perioperative VTE. The incidence of VTE is reduced with increasing duration of thromboprophylaxis after major orthopedic surgery, this association has not been shown for general surgery (5). Current guidelines of the American College of Chest Physicians recommend pharmacological prophylaxis for a minimum of 10-14 in major orthopedic surgery with the suggestion to extent it up to 35 days (3). Our patient received prophylactic dose of LMWH for 21 days after non-major orthopedic surgery. Except fracture, surgery and subsequent limited mobility no other strong/moderate risks factors for VTE were identified. Only weak risk factors such as increasing age and obesity were present. The patient had no previous history of VTE and laboratory tests for hypercoagulable states (including protein C and S, antithrombin III, factor V Leiden, prothrombin, lupus anticoagulant and antiphospholipid antibodies) were negative. Our patient was administered nadroparin $0.4 \mathrm{ml}$ s.c. once daily during the whole prophylaxis period, even though nadroparin $0.6 \mathrm{ml}$ s.c. once daily should have been started on day 4 after surgery (patient's weight was exceeding $70 \mathrm{~kg}$ ). We do not have an explanation for this reduced prophylactic LMWH dose in a patient with normal kidney functions. The prophylactic LMWH treatment was guided by traumatologists/orthopedists.

As a 21-day long pharmacological prophylaxis in our patient without additional risk factors was not sufficient to prevent VTE, we think that extended prophylaxis in orthopedic/traumatologic patients till full
Fig. 3. Partial occlusion (arrow) of superior mesenteric artery of $12 \mathrm{~mm}$ of length

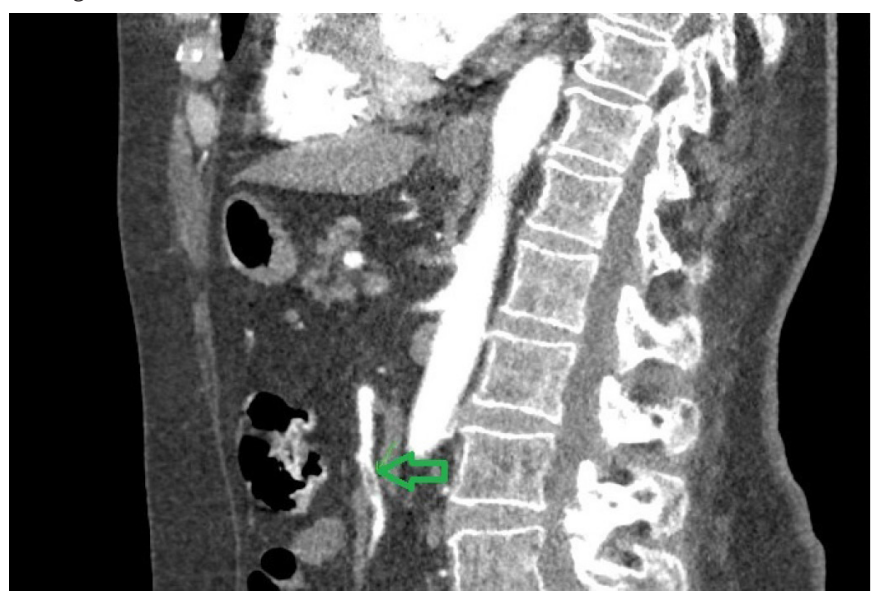

Fig. 4. Complete recanalization of the superior mesenteric artery

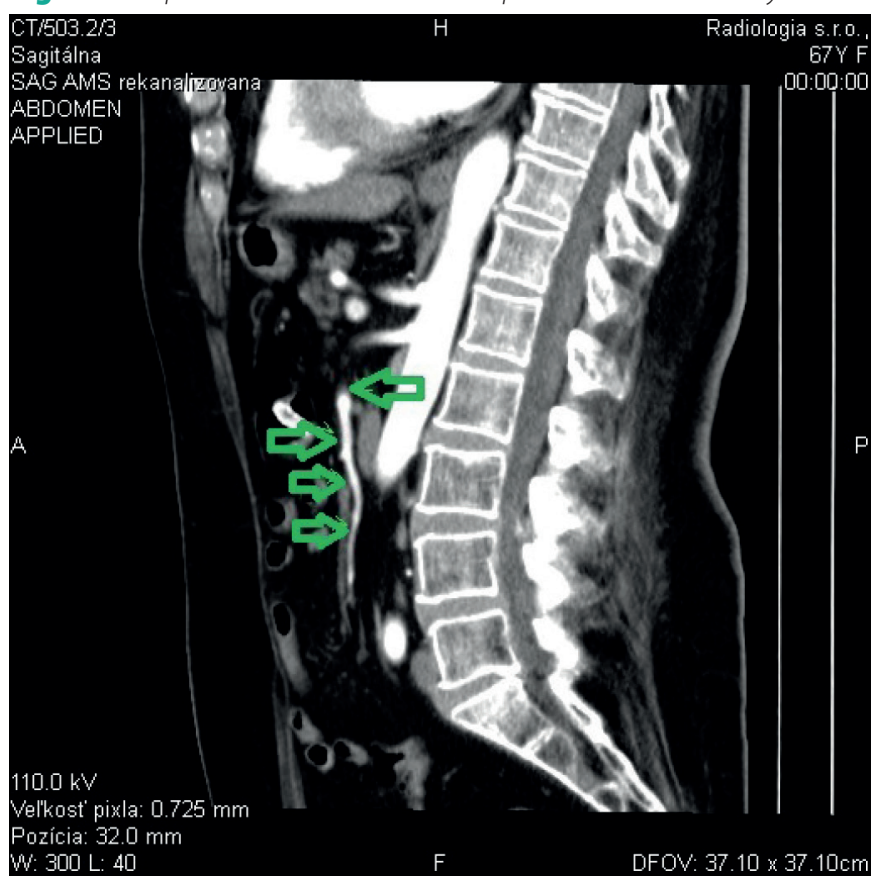

Fig. 5. Contrast transesophageal echocardiography with agitated dextrose showing patent foramen ovale, length of the channel $22 \mathrm{~mm}$, width of the channel $4.2 \mathrm{~mm}$ following Valsalva maneuver. Courtesy of Juraj Dubrava, MD, PhD., FESC, Head of the Department of Non-Invasive Cardiology, University Hospital Bratislava, St. Cyril and Method Hospital

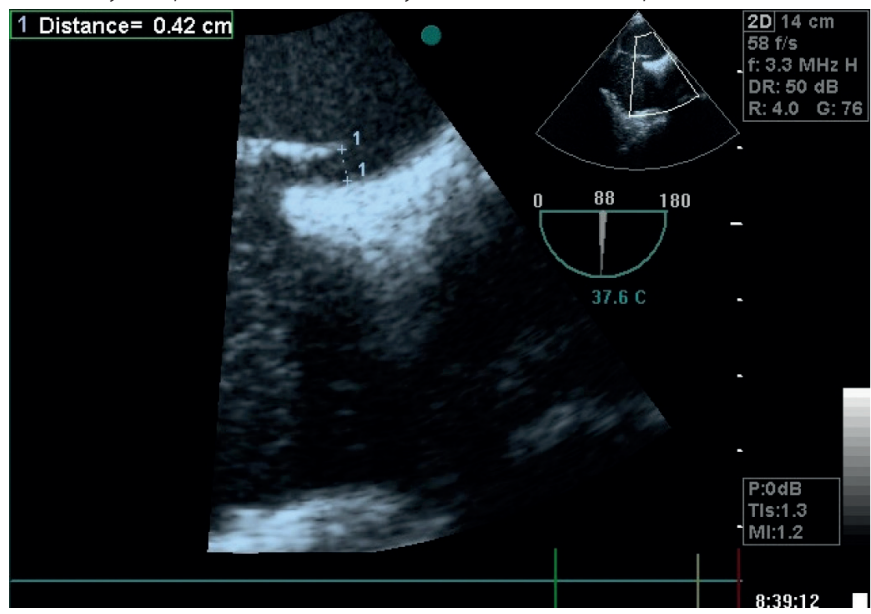


mobilization might be reasonable. However we acknowledge that the reduced prophylactic dose of $L M W H$ might have been a contributing factor in this particular case.

Patent foramen ovale is present in 10 to $35 \%$ of general population (4) and in one study it was diagnosed in $35 \%$ of patients with pulmonary embolism, accounting for a high risk of death and thromboembolic complications such as stroke and peripheral arterial embolism (8). However, patent foramen ovale accounts only for $2 \%$ of arterial emboli of the extremities (9). In our case, the left subclavian artery, left common femoral artery and superior mesenteric artery were involved. Paradoxical embolism into superior mesenteric artery is extremely rare $(10,11)$.

As the vascular surgeon decided against surgical embolectomy, local pulse spray thrombolysis was considered and interventional radiologist was consulted. Taking into account the presence of emboli at 3 different sites as well as the extent of each one of them, the radiologist decided not to perform pharmacomechanical thrombolysis. Local pulse spray thrombolysis was not applied in any of the few cases of multiple-site paradoxical embolism with concomitant pulmonary embolism we found in the literature, most authors report a combination of surgical embolectomy and systemic thrombolysis $(12,13)$.

Systemic thrombolysis with alteplase following the protocol for pulmonary embolism was attempted in this case, leading within 48 hours to the resolution of the emboli in the left subclavian artery, the common femoral artery and the superior mesenteric artery. Fan et al. described a similar case of systemic thrombolysis for pulmonary embolism and

\section{LIST OF REFERENCES}

1. White RH, Romano PS, Zhou H, et al. Incidence and time course of thromboembolic outcomes following total hip or knee arthroplasty. Arch Intern Med 1998; 158: 1525-1531. 2. Kearon C. Natural history of venous thromboembolism. Circulation 2003; 107: (23 Suppl 1): 122-130.

3. Kearon C, AkI EA, Comerota AJ, et al. Antithrombotic therapy for VTE disease: Antithrombotic Therapy and Prevention of Thrombosis, 9th ed: American College of Chest Physicians Evidence-Based Clinical Practice Guidelines. Chest 2012; 141: (2 Suppl): e419S-e496S. 4. Fisher DC, Fisher EA, Budd JH, et al. The incidence of patent foramen ovale in 1,000 consecutive patients. A contrast transesophageal echocardiography study. Chest 1995; 107: 1504-1509

5. Konstantinides SV, Torbicki A, Agnelli G, et al. 2014 ESC guidelines on the diagnosis and management of acute pulmonary embolism. Eur Heart J 2014; 35: 3033-3069, 3069a-3069k 6. Douketis JD, Eikelboom JW, Quinlan DJ, et al. Short-duration prophylaxis against venous thromboembolism after total hip or knee replacement: a meta-analysis of prospec tive studies investigating symptomatic outcomes. Arch Intern Med 2002; 162: 1465-1471. 7. Comp PC, Spiro TE, Friedman RJ, et al. Prolonged enoxaparin therapy to prevent venous thromboembolism after primary hip or knee replacement. Enoxaparin Clinical Trial Group. J Bone Joint Surg Am 2001; 83: 336-345.

8. Konstantinides S, Geibel A, Kasper W, et al. Patent foramen ovale is an important predictor o adverse outcome in patients with major pulmonary embolism. Circulation 1998; 97: 1946-1951. 9. AbuRahma AF, Downham L. The role of paradoxical arterial emboli of the extremities. Am J Surg 1996; 172: 214-217. concomitant multiple-site paradoxical embolism with involvement of the left subclavian artery and the origin of the celiac artery (12). Ruiz-Bailen et al reported a case of successful administration of alteplase in a venous thromboembolism crossing through a patent foramen ovale to the left atrium and suggest that thrombolysis could be a therapeutic option in the presence of a paradoxical embolism in the context of a serious VTE when surgery is not feasible (14). According to current ESC Guidelines on the Diagnosis and Treatment of Peripheral Arterial Diseases, therapeutic options for acute limb ischemia include thrombus extraction, thrombo-aspiration, surgical thrombectomy and catheter-directed thrombolytic therapy. Systemic thrombolysis has no role in the treatment of patients with acute limb ischemia (15). There are no guidelines addressing the treatment of multiple-site emboli in presence of PFO. Our case report supports the option of systemic thrombolysis for the treatment of multiple-site paradoxical embolism in context of pulmonary embolism when other therapeutic option (surgery, pharmacomechanical thrombolysis) is not possible.

\section{Conclusions}

Prolonged antithrombotic prophylaxis might be reasonable in patients after orthopedic/traumatologic surgery until full mobilization.

Systemic thrombolysis may be attempted in case of multiple-site paradoxical embolism through patent foramen ovale, especially in cases where other treatment options (surgery, pharmacomechanical thrombolysis) are not possible.

10. Acosta S, Bjorck M. Acute thrombo-embolic occlusion of the superior mesenteric artery: a prospective study in a well defined population. Eur J Vasc Endovasc Surg 2003; 26: 179-183

11. Pirkl M, Myjavec A, Danek T, et al. A case of pulmonary thromboembolism with synchronous and metachronous paradoxical embolism through the patent foramen ovale. Cor et Vasa 2012; 54: E314-E322.

12. Fan Z, Roedersheimer R, Lohr J. Systemic thrombolysis using tissue plasminogen activator for a patient with paradoxic embolism: a case report. Vasc Endovascular Surg 2007; 41: 136-139.

13. Agarwal SK, Binbrek AS, Thompson JA, et al. Massive pulmonary embolism and acute limb ischaemia in a patient of hereditary spherocytosis and patent foramen ovale. Heart Lung Circ 2010; 19: 742-744.

14. Ruiz-Bailen M, Ramos-Cuadra JA, Machado-Casas J, et al. Successful administration of alteplase in a venous thromboembolism crossing through a patent foramen ovale. Interact Cardiovasc Thorac Surg 2009; 9: 712-713.

15. Aboyans V, Ricco JB, Bartelink MEL, et al. 2017 ESC Guidelines on the Diagnosis and Treatment of Peripheral Arterial Diseases, in collaboration with the European Society for Vascular Surgery (ESVS): Document covering atherosclerotic disease of extracranial carotid and vertebral, mesenteric, renal, upper and lower extremity arteries Endorsed by: the European Stroke Organization (ESO)The Task Force for the Diagnosis and Treatment of Peripheral Arterial Diseases of the European Society of Cardiology (ESC) and of the European Society for Vascular Surgery (ESVS). Eur Heart J 2018; 39: 763-816. 